\title{
The Proposal for the Model of Users' Addictions in Social Gaming
}

I. Introduction

II. Literature Review

III. Method

IV. Results

$\checkmark$. Conclusions

References

ABSTRACT

Tengku Fauzan Tengku Anuar, Song Seung Keun*

\section{초 록}

본 연구의 목적은 소셜네트웍게임에서 사용자 중독에 대한 새로운 모델을 제안 하고자 한다. 본 모델은 논리적 특성과 정서적 특성에서 유래한다. 논리적 특성은 기능 $(\mathrm{F})$, 키스트록 $(\mathrm{K})$, 목표 $(\mathrm{G})$ 로 구성된다. 정서적 특성은 감정 $(\mathrm{E})$, 사교 $(\mathrm{S})$, 감성 (A)으로 구성된다. 30명의 참가자를 통해서 예비조사를 실시하여 설문문항의 적합 성, 대략적인 모형의 타당성 및 연구의 방향성 등을 점검하였다. 이후 본 연구에서 300 명의 피험자를 대상으로 조사를 실시하였다. 그중 261명만 채택하였다. 왜냐하 면 39명은 SNG 게임을 전혀 해보지 않았으며 설문 응답에 불성실하게 이행하여 본 연구에서 제외하였다. 본 연구는 부분최소자승-구조방정식모델링 기법을 활용 하여 가설검증을 하였다. 그 결과 모형적합도가 높게 나타났으며 12가지 가설 가 운데 11 가지가 유의미한 효과가 발생하였다 $(\mathrm{H} 1, \mathrm{H} 2, \mathrm{H} 3, \mathrm{H} 4, \mathrm{H} 5, \mathrm{H} 6, \mathrm{H} 7, \mathrm{H} 8$, $\mathrm{H} 9, \mathrm{H} 10, \mathrm{H} 12)$. 그러나 유일한 가설 $\mathrm{H} 11$ 인 소셜네트워크중독과 키스트록 간에는 유의미한 효과가 발생하지 않았다. 본 연구는 소셜네트워크게임 개발을 위한 사용 자 행동을 이해하며 중독의 기저를 밝히는데 기초가 되는 탐색적 연구가 될 것으 로 기대된다.

주제어 : 중독, 소셜게임, 구조방적식모델 


\section{I . Introduction}

As people increasingly play 'Social Network Games' (SNGs), numerous new features have been proposed to increase players log-on time at SNGs. However, few studies have investigated why people continue to play certain SNGs or which design features are most closely related to the amount of time spent by players at particular SNGs. This study proposes a theoretical model using the concepts of 'Functional' (F), 'Keystroke' (K), 'Goal' (G), 'Emotion' (E), 'Social' (S) and 'Affection' (A) that derived towards 'SNGs Addictions' (SNGA) to explain why people continue to play SNGs.

The study then conducts a survey to validate the model. As we know internet users often want to meet and communicate with other people, just as they do in the real world. The social network is a social community via online communication, where people meet online to post messages and pictures, chat, and play games. An increasing number of games have found their way onto these platforms. Among SNSs, the number of Facebook users is quickly increasing, with over 1441 million users throughout the world in 2015, compared to the 431 million users in 2010.1) Facebook applications attract millions of users, and game applications frequently reach the top-10 popularity lists of the platform online social network games, have spawned a whole new subculture. ${ }^{2)}$

* 이 논문은 2014 년도 동서대학교 학술연구조성비 지원과제의 연구비에 의하여 연구되었음.

1) http://www.google.co.kr Retrieval Word = Statistics Facebook, 2015 ht tp://www.stat ista.com/stat ist ics/264810/number-of-monthly-act ivefacebook-users-worldwide/ 2015.7.28.

2) Shin, D., Shin, Y., "Why do people play social network games?", 
Compared to online games, SNGs are played through social networks, and typically features multiplayer. However, if a person is not satisfied with current SNGs, he/she will switch to other SNGs. Since a person can easily switch from one SNG to another, user retention is an important issue.

SNGs are a mass phenomenon and, for most of the users, a social activity. Even though there are numerous studies on SNGs they do not explicitly investigate the offline contacts of the gamers, which play a significant role for their social embedded-ness. Regarding the online gaming related contacts possible strong ties such as friendship relationships are often neglected.

Additionally modality switching between the two spheres, logical characteristics and feeling characteristics is not further investigated. This study will fill its gap between both ones. In this paper, we strive to extend the research on the interrelation of SNGs use and the social embedded-ness of SNGs gamers, as well as modality switching between two characteristic contexts as we mention in $<$ Figure $1>$.

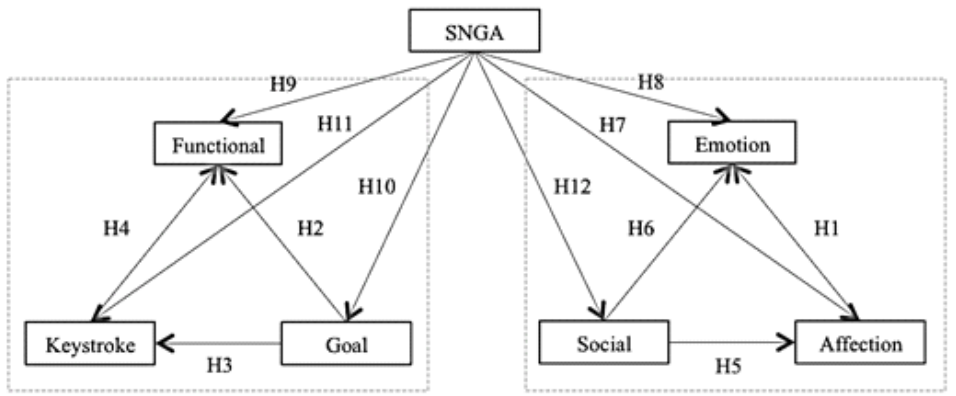

Logical Characteristics

Feeling Characteristics

Figure 1. Proposed Research Model

Computers in Human Behavior, Vol.27(2011), pp.852-861. 
Therefore, this study proposed that the new research model representative of a high level of customer satisfaction and influences of SNGs addiction. Instead, the emphasis is on building theoretical logic that links user satisfaction and flow experience to continued use of the SNG. These models will highlight the major antecedents and determinants that can explain a large portion of the variance in SNGs addictions. This model enables us to link continued use with its predicting variables. We examined the measurement model to test reliability and validity on each construct. Then we performed structural equation modeling analysis to test the research hypotheses empirically.

\section{Literature Review}

\section{Social Network Games Addictions}

The rapid growth of the Internet has come with questions about its impact on society and users, both positive and negative. Typically, Internet Addiction is one of these negative effects. Some empirical studies have been done in recent years and most of them focused on several key factors related to internet addiction ${ }^{3)}$ including life stressors4), family-related factors ${ }^{5}$ and especially personality

3) Kuss,D.J., Griffiths,M.D., and Binder,J.F., "Internet addiction in students: Prevalence and riskfactors", Computers in Human Behavior, Vol.29(2013), pp. 959-966.

4) Lam,L.T., Peng,Z., Mai,J., Jing,J., "Factors Associated with Internet Addiction among Adolescents", CyberPsychology \& Behavior, Vol.12(2009), pp. 551-555.

5) Ko,C., Hsiaod,S., Liud,G., Yena, J., Yang, M., Yen,C., "The characteristics of decision making, potential to take risks, and personality of college students with Internet addiction", Psychiatry Research, Vol.175 (2010), pp. 121-125. 
characteristics and psycho social characteristics. ${ }^{6)}$

There is also finding that high levels of loneliness, social anxiety, and neuroticism as well as low levels of extraversion influenced the Internet addictions. Social psychological or personality variables, such as sensation seeking, loneliness, depression, poor motivation, fear of rejection, and the need for approval, are associated with this addictive behavior. ${ }^{7}$ )

The psychological motives and reasons for playing online games and video games have also been explored. It is reported that entertainment and leisure, emotional coping, excitement and challenge seeking and escape from reality maybe the major reasons for playing online games. ${ }^{8)}$ Other studies focused on the issue of why players continued to play online games. ${ }^{9)}$ They found that some characteristics of online games might keep users continuous playing. Leveling-up and obtaining items as well as the recognition and admiration of other players are the major attractions for many players in MMORPGs. 10) Good Cutscenes can motivate to engage players in video games. 11)

6) Andreou,E., Svoli,H., "The Association Between Internet User Characteristics and Dimensions of Internet Addiction Among Greek Adolescents", International Journal of Mental Health and Addiction, Vol. 11(2013), pp. 139-148.

7) Hardie, E., Tee, M.Y., "Excessive Internet Use: The Role of Personality, Loneliness and Social Support Networks in Internet Addictions", Australian Journal of Emerging Technologies and Society, Vol.5(2007), pp. 34-47.

8) Griffiths,M.D., Davies,M.N.O., and Chappell,D., "Onl ine computer gaming: a comparison of adolescent and adult gamers", Journal of Adolescence, Vol.27(2004), pp. 87-96.

9) Siang,A.C.,Zaphiris,P., and Mahmood,S., "A model of cognitive loads in massively multiplayer online role playing games", Interacting with computers. Vol.19(2007), pp. 167-179.

10) Brian, D. N., Peter, W., "Addiction to the Internet and Online Gaming", CyberPsychology \& Behavior, Vol. 8(2005), pp. 110-113. 
As SNGs become increasingly popular, the problem of game addiction has received much attention. The game industries have, understandably, employed various design strategies in order to increase consumer' $s$ engagement and loyalty, but it is easily ignored that over attraction maybe result in addiction. Computer designs have been found to have many important influences on a user' s psychology, so that the relationship between a user' s liking of the design factors and addiction is worthy of our attention and investigation, but in fact, only few of studies examined it.

Based on aforementioned studies, we can conclude that factors associated with Internet addiction were complicated and the SNGs should be given special attention. ${ }^{12)}$

Although several studies examined player backgrounds, characteristics, and motives, few have addressed the relationship between SNGs addiction and game design. With the limited researches in this field, the relationship between SNGs attraction and SNGs addiction should be further explored. Activities such as online interactive gaming may contribute to pathological Internet use, the magnitude of this influence is unclear. ${ }^{13)}$

SNGs have a special influence on Internet addiction; however, the mechanism of this influence and the aspects of SNGs that appeal to users have not been clarified. Moreover,

11) Ruan, X.,Cho, D.,"Relation between Game Motivation and Preference to Cutscenes", The Korean Society of Cartoon \& Animation Studies, Vol. 36(2014), pp.573-592.

12) Song, I., Larose,R., Eastin,M.S., and Lin,C.A., "Internet Gratifications and Internet Addiction: On the Uses and Abuses of New Media", CyberPsychology \& Behavior, Vol. 7(2004), pp.384-394.

13) Janet, M., "Internet Abuse: Emerging Trends and Lingering Questions", in Azy Barak,(eds.), Psychological aspects of cyberspace: theory, research, applications, Cambrigde, 2008. 
it is unknown how SNGs, together with the major factors of characteristics will impact SNGs addiction in consumers or which of the above factors contributes most to SNGs addiction. The present study sought to answer these questions by examining SNGs.

\section{Key Factors in SNGs' Addiction}

From the review of literature, interviewed, observations and pilot test, we come out with the key factors as a construct to be tested. According to Lazzaro, the goal of testing is to improve quality. However, there is more to software quality than ease of use. There is a lot more going on for games. Without usability no one can play a game, make it to usable and it's no fun. That's the difference between 'User Experience Design' (UX) and 'Player Experience Design' (PX). Games create emotion from experiences that usability and traditional market research cannot measure. Other method can, and designers who can assess a player's emotional responses early in the development cycle can innovate with much less risk. ${ }^{14)}$

Therefore, our research model involved the separation of two characteristic such as 'Logical' characteristic that includes 'Functional' (F), 'Keystroke' (K) and 'Goal' (G). Mean while, 'Feeling' characteristic consist a few factor such as 'Emotion' (E), 'Social' (S) and 'Affection' (A) that derived towards 'SNGs Addictions' (SNGA). The interaction between this factor have been found to influence user satisfaction and flow experience.

14) Isbister,K., Schaffer,N., Game Usability: Advancing the Player Experience, Morgan Kaufmann, MA 2008, pp 317-343. 


\subsection{Functional-level Factor}

The functional level provides more detail than the unit-task level. Functional level are where users at the level of searching a block or killing an enemy. The task is so constrained that there are virtually no situations in which alternative methods arise, so selection rules do not play a role in these analyses. Time estimates for the decision making are based on time estimates for each of users'. It is a simplifying assumption of GOMS models that each operator (at any level of analysis) has an estimated duration that may depend on inputs to that operator but not on the context of other operators in which it occurs. 15) The functional-level operators we chose to define herein do not have such task-dependent inputs; each users' has just one time estimates despite the fact that it covers a variety of task situations. For instance, the information receive by users' represents behavior ranging.

\subsection{Keystroke-level Factor}

Keystroke level, where users are at the level of individual finger movements on the game' $s$ control panel. Each level is considered a separate GOMS analysis, as in Chapter 5 of Card, Moran, \& Newell. The analyses will be described in parallel, beginning with the goals, operators, methods and selection rules for each, then describing the process of applying this information to the task of playing the game. ${ }^{16)}$

15) Gray,W.D., John,B.E., and Atwood,M.E., "Project Ernestine: Validating a GOMS analysis for predicting and explaining real-world task performance", Human Computer Interaction, Vol.8.(1993), pp. 237-309.

16) John,B.E., Kieras,D.E., "The GOMS family of user interface analysis techniques: comparison and contrast", Journal ACM Transactions on 


\subsection{Goal Factor}

For our analysis, we also developed preferences to select a Goal as a construct. People play games to change or structure their internal experiences. Adults in her study enjoy filling their heads with thoughts and emotions unrelated to work or school, others enjoy the challenge and chance to test their abilities. Games offer an efficiency and order in playing that they want in life. They value the sensations from doing new things such as dirt bike racing or flying, that they otherwise lack the skills, resources, or social permission to do. A few like to escape the real world; others enjoy escaping its social norms. Nearly all enjoy the feeling of challenge and complete absorption. The exciting and relaxing effects of games is very appealing and some apply its therapeutic benefits to "get perspective," calm down after a hard day, or build self-esteem. ${ }^{17)}$

Direct observation reveals details about player emotion. They found the emotion in player' s visceral, behavioral, cognitive, and social responses to games. Players play to experience these body sensations that result from and drive their actions. Some crave the increased heart rate of excitement from a race, the skin prickling sensation from Wonder, or the tension of Frustration followed by feelings of Fiero. For others it is simply the exchange of worries and thought and feelings for relaxation and contentment or a feeling of achievement knowing they did it right or not.

Computer-Human Interaction (TOCHI), Vol.3 (1996), pp. 320-351.

17) Nicole.L., "Why we play games: Four keys to more emotion without story", http://ww.xeodesign.com/xeodesign_whyweplaygames.pdf 2015.7.28. 


\subsection{Social Interaction Factor}

Social interaction is defined as the two or more objects communicating and affecting each other. In computer gaming, as well as in some other applications, interaction is considered one of the most important aspects of optimal experience with computer games. Interaction may include expressions of encouragement, excitement, or frustration or the exchange of strategies and tips about games, all of which can be highly reinforcing.

In this research interactions while playing online games can be classified into two types: the interaction between the user and the system (i.e., human-computer interaction) and user-to-user interaction (i.e., social interaction). In this study, the interaction between the user and system is referred to as human-computer interaction, and the term social interaction refer to the interaction between two or more users. The human computer interface, defined, as the system' $s$ point of contact between the application and the end user, is that which enables the user and the computer to communicate. 18) However, the human-computer interaction refers to users ability to communicate with machines using their natural communication skills, which interactive experiences are more personal, emotional, meaningful, enjoyable, and effective.

In summary, social interaction and human-computer interaction have been found to influence user satisfaction and flow experience. Social interaction could cause immersion in games. Players enjoyment came from interaction with other people and flow experience can happen in

18) Chalmers,P.A., "The role of cognitive theory in human-computer interface", Computers in Human Behavior, Vol.19 (2003), pp. 593-607. 
interaction with information technology. Therefore, it is reasonable to expect that human-computer interaction and social interaction will increase players satisfaction by helping them to enter a flow state, thereby promoting their intention to accept SNGs.

\subsection{Emotion Factor}

Emotion is certainly revealed as much as psychological change and has been verified sensibly. Even physiological change has been observed. It has also become a major part of the scientific research subject because objective measurement and evaluation have long been possible. Emotional reactions to success and failure in achievement-oriented tasks have a significant function in SNGs achievement motivation.

\subsection{Affection Factor}

Despite the recent increased interest in social games, scientific study about users affection in social games is lacking. One study on affection from Kansei Engineering in Japan determined that affection terms have spread actively across academia after originating from Mazda' s success. 19) This research explained the affection factor that suitable for SNGs in order to build a structure and investigate affection through the tests used in psychology as an al ternative. 20$)$

19) Lee,S., Yang, S., Human Sensibility Ergonomics , ChungMoonKak, 1996.

20) Choi, H., Choi,E., and Song.S., "The structure of affection descriptors for social network game: case study of CityVille on facebook", Multimedia Tools and Applications, Vol.68 (2014), pp. 375-389. 


\section{Method}

\section{Research Model}

As depicted in Figure 1, research model is derived from the separation of logical and feeling characteristic found in SNGs literature which is consist a few factor such as 'Functional' (F), 'Keystroke' (K), 'Goal' (G), 'Emotion' (E), 'Social' (S) and 'Affection' (A) that derived towards 'SNGs Addictions' (SNGA). The objective is not to propose a model that delineates all of the links explaining SNGs addictions nor is it to generate a list of possible antecedents that affect satisfaction and flow experience; furthermore determine the continuance intention of using SNGs. Instead, the emphasis is on building theoretical logic that links user satisfaction and flow experience to cont inued use of the SNG.

Therefore, model highlights the major antecedents and determinants that can explain a large portion of the variance in SNGs addictions. Model enables us to link continued use with its predicting variables. We examined the measurement model to test reliability and validity. Then we performed structural equation modeling analysis to test the research hypotheses empirically. Thus, the following hypotheses in <Table $1>$ are proposed.

\begin{tabular}{|c|c|}
\hline $\begin{array}{c}\text { Hypothesis } \\
(\mathrm{H})\end{array}$ & Proposed Hypothesis \\
\hline $\mathrm{H} 1: \mathrm{A}->\mathrm{E}$ & $\begin{array}{c}\text { 'Affection' interaction is positively related } \\
\text { to the user 'Emotion' toward cont inuously } \\
\text { using SNGs }\end{array}$ \\
\hline $\mathrm{H} 2: \mathrm{G}->\mathrm{F}$ & $\begin{array}{c}\text { 'Goal' has a positive effect on 'Functional' } \\
\text { level toward continuously using SNGs }\end{array}$ \\
\hline
\end{tabular}




\begin{tabular}{|c|c|}
\hline H3: $G->K$ & $\begin{array}{c}\text { 'Goal' has a positive effect on 'Keystroke' } \\
\text { level toward continuously using SNGs }\end{array}$ \\
\hline $\mathrm{H} 4: \mathrm{K}->\mathrm{F}$ & $\begin{array}{l}\text { Users who have better 'Keystroke' level } \\
\text { experiences are more likely to have } \\
\text { continuance intentions of using SNGs should } \\
\text { know the 'Functional' level }\end{array}$ \\
\hline H5: S->A & $\begin{array}{c}\text { 'Social' interaction is positively related to } \\
\text { the user 'Affection' toward continuously using } \\
\text { SNGs }\end{array}$ \\
\hline $\mathrm{H} 6: \mathrm{S}->\mathrm{E}$ & $\begin{array}{c}\text { 'Social' interaction is positively related to } \\
\text { the user 'Emotion' toward continuously using } \\
\text { SNGs }\end{array}$ \\
\hline H7: SNGA->A & $\begin{array}{l}\text { Users who experience greater 'SNGs Addictions' } \\
\text { level are more likely to achieve a greater } \\
\text { flow experience in user 'Affection' toward } \\
\text { continuously using SNGs }\end{array}$ \\
\hline H8: SNGA->E & $\begin{array}{l}\text { Users who experience greater 'SNGs Addictions' } \\
\text { level are more likely to achieve a greater } \\
\text { flow experience in user 'Emotion' toward } \\
\text { continuously using SNGs }\end{array}$ \\
\hline H9: SNGA $\rightarrow \mathrm{F}$ & $\begin{array}{l}\text { Users who experience greater 'SNGs Addictions' } \\
\text { level are more likely to achieve a greater } \\
\text { flow experience in user 'Functional' toward } \\
\text { continuously using SNGs }\end{array}$ \\
\hline H10: SNGA $>\mathrm{G}$ & $\begin{array}{l}\text { Users who experience greater 'SNGs Addictions' } \\
\text { level are more likely to achieve a greater } \\
\text { flow experience in user 'Goal' toward } \\
\text { continuously using SNGs }\end{array}$ \\
\hline H11: SNGA->K & $\begin{array}{l}\text { Users who experience greater 'SNGs Addictions' } \\
\text { level are more likely to achieve a greater } \\
\text { flow experience in user 'Keystroke' toward } \\
\text { continuously using SNGs }\end{array}$ \\
\hline H12: SNGA $>$ S & $\begin{array}{l}\text { Users who experience greater 'SNGs Addictions' } \\
\text { level are more likely to achieve a greater } \\
\text { flow experience in user 'Social' Interaction } \\
\text { toward continuously using SNGs }\end{array}$ \\
\hline
\end{tabular}

Table 1. Proposed Hypothes is 


\section{Procedure}

\subsection{Pilot test}

For the pre-test, we collected 34 questionnaire items from relevant literatures. A pretest survey questionnaire was conducted to confirm the validity and reliability of the construct. A total of 30 participants from university in Korea responded to the questionnaire survey. The respondent group ranged in age from 20 to 30 , and 56.7 percent of participants were female. Most subjects reported spending more than one hour per week on SNG usage. Therefore, participants were familiar with interactive SNGs on the SNS.

We conduct an interview to pre-test the questions for our seven variables. 'Functional' (F), 'Keystroke' (K), 'Goal' (G), 'Emotion' (E), 'Social' (S) and 'Affection' (A) \& 'SNGs Addictions' (SNGA). Results of the pretest study showed that validity of these questionnaire items was confirmed. We randomly selected a sample of SNGs users in South Korea. Then we used a convenience sample of university students because young students represent the majority of Internet users in Korea and also young generation is likely to be the most active Internet users participating in various on line transaction services in the near future.

Although the use of a collage/university student is not ideal, there is evidence that collage/university student are in many ways similar to SNS' $\mathrm{s}$ and online game users more generally.21)

21) Hargittai,E., "Whose space? Differences among users and non-users of social network sites", Journal of Computer-Mediated Communication, Vol. 13(2008), pp. 276-297. 


\subsection{Main test}

After the questions developed in pre-test, we conducted a survey in Korea to test our model. Respondents were advised that the survey was for SNGs users and were asked before being presented with the survey, weather they had used SNGs before or not. A total 300 people participated. Only those who had used SNGs at least once before completing the survey were retained. The final number of effective participants was 261. Among the final effective respondents, there were more female participants than male. <Table 2> provides the demographic profile of the subjects.

\begin{tabular}{|c|c|c|c|}
\hline \multicolumn{2}{|c|}{ Demographic Profile $(n=261)$} & Frequency & Percent $(\%)$ \\
\hline \multirow{2}{*}{ Gender } & Female & 120 & 46.0 \\
\hline & Male & 141 & 54.0 \\
\hline \multirow{4}{*}{ Age } & Under 20 & 47 & 18.0 \\
\hline & $21-25$ & 175 & 67.0 \\
\hline & $26-30$ & 37 & 14.2 \\
\hline & $31-36$ & 2 & 0.8 \\
\hline \multirow{3}{*}{ Education } & Collage & 5 & 1.9 \\
\hline & Undergraduate & 216 & 82.8 \\
\hline & $\begin{array}{c}\text { Post-Graduate/abo } \\
\text { ve }\end{array}$ & 40 & 15.3 \\
\hline \multirow{4}{*}{$\begin{array}{c}\text { A Period of SNG's } \\
\text { Experience }\end{array}$} & 2-3 Months & 56 & 21.5 \\
\hline & 3-6 Months & 14 & 5.4 \\
\hline & 6-12 Months & 14 & 5.4 \\
\hline & Over 1 Year & 177 & 67.8 \\
\hline \multirow{4}{*}{$\begin{array}{c}\text { Mean Times to play } \\
\text { SNG's per week } \\
\text { (hours) }\end{array}$} & 1-2 Hours & 117 & 44.8 \\
\hline & $2-4$ Hours & 56 & 21.5 \\
\hline & 4-6 Hours & 43 & 16.5 \\
\hline & Over 6 Hours & 45 & 17.2 \\
\hline \multirow{2}{*}{ SNG's Platform } & Facebook & 51 & 19.5 \\
\hline & KakaoTalk & 210 & 80.5 \\
\hline
\end{tabular}




\begin{tabular}{|c|c|c|c|}
\hline \multirow{4}{*}{$\begin{array}{c}\text { Typed of SNG's } \\
\text { Played }\end{array}$} & Act ion & 14 & 5.4 \\
\cline { 2 - 4 } & Puzzle & 87 & 33.3 \\
\cline { 2 - 4 } & RPG & 62 & 23.8 \\
\cline { 2 - 4 } & Running & 55 & 21.1 \\
\cline { 2 - 4 } & Simulation & 43 & 16.5 \\
\hline
\end{tabular}

Table 2. Characteristic of Respondents

\section{Results}

\section{Statistical Analysis}

All constructs were measured using multiple items and used fully anchored, five-point, Likert-type scales ranging from strongly disagree to strongly agree. In this study, data analysis was conducted using a variance maximization approach to structural statistical analysis with associated statistics for validity and reliability using SmartPLS to compute the Cronbach Alpha reliability of the analyses. Following the two-step approach we used, the data analysis included two steps.

First, we examined the measurement model which is in this stage it involves the assessment of validity and reliability of the indicators (items). Then we performed Partial Least Squares - Structural Equation Modeling (PLS-SEM) analysis to test the research hypotheses empirically. This stage involves the assessment of relationship between latent constructs and other latent constructs which is also where the hypotheses are tested.

\section{Validity and Reliability of the Measurement}

We conducted a confirmatory factor analysis to test the convergent and discriminant validity of the survey 
questions. <Table 3> shows the standardized factor loading, AVE(Average Variance Extracted), CR(Composite Reliability), and Cronbach a .

Results shown in <Table $3>$ verify the discriminant validity of the questionnaire items used in our study, because the AVE for each construct exceeds the squared correlation between that construct and any other construct.

\begin{tabular}{|c|c|c|c|c|c|}
\hline Construct & Item & $\begin{array}{c}\text { Loading } \\
\mathrm{s}\end{array}$ & AVE & CR & $\begin{array}{c}\text { Cronbachs } \\
\text { Alpha }\end{array}$ \\
\hline \multirow{5}{*}{ Affection } & A10 & 0.801 & \multirow{5}{*}{0.596} & \multirow{5}{*}{0.880} & \multirow{5}{*}{0.830} \\
\hline & A11 & 0.855 & & & \\
\hline & $\mathrm{A} 12$ & 0.770 & & & \\
\hline & A4 & 0.737 & & & \\
\hline & A6 & 0.687 & & & \\
\hline \multirow{5}{*}{ Emot ion } & E1 & 0.782 & \multirow{5}{*}{0.613} & \multirow{5}{*}{0.888} & \multirow{5}{*}{0.842} \\
\hline & E2 & 0.811 & & & \\
\hline & E5 & 0.771 & & & \\
\hline & E6 & 0.761 & & & \\
\hline & E7 & 0.789 & & & \\
\hline \multirow{4}{*}{$\begin{array}{c}\text { Funct iona } \\
1\end{array}$} & F4 & 0.915 & \multirow{4}{*}{0.805} & \multirow{4}{*}{0.943} & \multirow{4}{*}{0.920} \\
\hline & F6 & 0.921 & & & \\
\hline & F7 & 0.869 & & & \\
\hline & F8 & 0.882 & & & \\
\hline \multirow{5}{*}{ Goal } & G10 & 0.740 & \multirow{5}{*}{0.618} & \multirow{5}{*}{0.889} & \multirow{5}{*}{0.845} \\
\hline & G3 & 0.800 & & & \\
\hline & G5 & 0.732 & & & \\
\hline & G7 & 0.828 & & & \\
\hline & G8 & 0.824 & & & \\
\hline \multirow{5}{*}{ Keystroke } & K1 & 0.699 & \multirow{5}{*}{0.534} & \multirow{5}{*}{0.851} & \multirow{5}{*}{0.791} \\
\hline & K3 & 0.775 & & & \\
\hline & K6 & 0.748 & & & \\
\hline & K7 & 0.656 & & & \\
\hline & K8 & 0.768 & & & \\
\hline
\end{tabular}




\begin{tabular}{|c|c|c|c|c|c|}
\hline \multirow{5}{*}{ Social } & S11 & 0.823 & \multirow{5}{*}{0.722} & \multirow{5}{*}{0.928} & \multirow{5}{*}{0.903} \\
\hline & $\mathrm{S} 2$ & 0.768 & & & \\
\hline & S3 & 0.875 & & & \\
\hline & S6 & 0.893 & & & \\
\hline & S7 & 0.883 & & & \\
\hline \multirow{5}{*}{ SNGA } & SNGA10 & 0.833 & \multirow{5}{*}{0.584} & \multirow{5}{*}{0.875} & \multirow{5}{*}{0.821} \\
\hline & SNGA11 & 0.688 & & & \\
\hline & SNGA2 & 0.728 & & & \\
\hline & SNGA5 & 0.754 & & & \\
\hline & SNGA8 & 0.809 & & & \\
\hline \multicolumn{6}{|c|}{$\begin{array}{c}\text { AVE = Average Variance Extracted;CR = Composite Reliability } \\
\text { Compare with the benchmarks given in the literature; for } \\
\text { loadings }(>0.7) \text {, CR }(>0.7) \text { and AVE }(>0.5) \text {. If the values are } \\
\text { all above the cut off values then you can say that the measures } \\
\text { have sufficient convergent validity. }\end{array}$} \\
\hline
\end{tabular}

Table 3. Measurement Model

\section{Summary of the Research Result}

This study developed a theoretical framework describing a motivation based decision making process and tested the proposed model using a structural equation modeling technique on SNG user behavior. The results aid understanding of users attitudes and intentions towards SNGs, and clarify the implications for the development of effective SNG services and applications.

Under the measurement model, two types of validity were assessed which is involved Convergent Validity and Discriminant Validity. Convergent validity which is the degree to which multiple items to measure the same concepts are in agreement. Factor loadings, composite reliability and average variance extracted are used to assess convergence validity. ${ }^{22)}$

22) Hair,J.F.Jr., Hult,G.T.M., Ringle, C., Sarstedt, M., A Primer on Partial Least Squares Structural Equation Modeling (PLS-SEM), SAGE 
PLS enables the assessment of a model' $s$ measures by providing an assessment of the reliability of the scales, along with their convergent and discriminant validity. Adequate reliability was demonstrated for all of the measures across all of the scenarios because, the loadings for all the constructs are above 0.6, indicating that less than half of any indicator' $s$ variance was due to error. In addition, all composite scale reliabilities (similar to Chronbach' s alpha) shown also were exceed the recommended cutoff of 0.7 . The results also shown average variances extracted (AVE) by the scales exceeded the recommended cutoff of 0.5 .

Convergent and discriminant reliability is demonstrated in two ways. First, the square root of the average variance extracted (AVE) for each construct exceeds its correlation with any other latent variable. The discriminant validity which is the degree to which items differentiate among constructs or measure distinct concepts by examining the correlations between the measures of potentially overlapping constructs. Items should load more strongly on their own constructs in the model, and the average variance shared between each construct and its measures should be greater than the variance shared between the construct and other constructs. ${ }^{23)}$

This shows that each construct shares more variance with its indicators than it shares with the other constructs. The criteria for assessment are the values in the diagonal

Publications, 2014.

23) Mun,Y., and Hwang,Y., "Predicting the use of web-based information systems: self-efficacy, enjoyment, learning goal orientation, and the technology acceptance model." International journal of human-computer studies, Vol.59 (2003), pp. 431-449. 
should be higher than all other values in the row and column. If that is exhibited then we can conclude the measurements have discriminant validity.

Second, another way of assessing discriminant validity is by looking at the cross loadings table (see Table 3). Tables 3 shows (loadings and cross-loadings) that each measure loads higher (shares more variance) on its own construct than it loads on any of the other constructs.

The results of the measurement and structural model test lend support to the proposed research model by providing a good fit to the construct data. The measurement model construct to test reliability and validity and the result showed most of the numbers are closed to Alpha $=.9365$, which means the entire construct that we purpose in this research, is reliable. Most of the scores were above the acceptable level, that is, above 0.70 .

We also used significant path coefficients in the model in order to test the structural relationships and the estimated hypothesized causal paths. Partial Least Squares Algorithm was used. The PLS path modeling method was developed by Herman Wold and the PLS algorithm is essentially a sequence of regressions in terms of weight vectors. The weight vectors obtained at convergence satisfy fixed-point equations. ${ }^{24)}$

$<$ Figure $2>$ show all result in positive axis. Overall, the results forreliability and content validity show most of the hypothesized associations are supported and significant. The models demonstrate good analytical powers and explain

24) Dijkstra,T.K., "Latent variables and indices: Herman Wold' s basic design and partial least squares", In: Vinzi VE, Chin WW, Henseler J, Wang $H$ (eds) Handbook of partial least squares, Springer Handbooks of computational statistics, 2010, pp. 23-46. 
behavioral intentions in SNGs will be further explored.

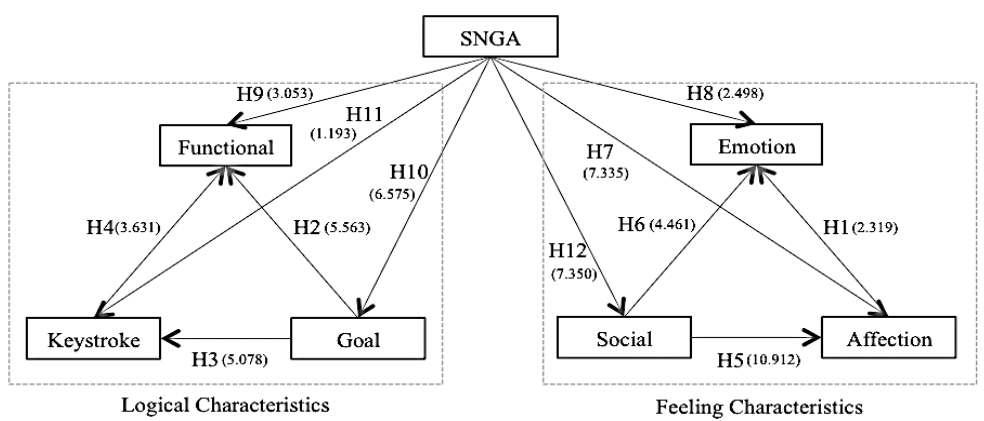

Figure 2. Research Result

In investigating overall acceptance of SNGs, $t$-value test were tested based on the interaction effect between H1, H2, H3, H4, H5, H6, H7, H8, H9, H10, H11 \& H12.

If the t-value greater than $1.645(\mathrm{p}<0.05)$ and if the $\mathrm{t}$-value greater than $2.33(\mathrm{p}<0.01)$ for 1 -tal test and if the $\mathrm{t}$-value greater than $1.96(\mathrm{p}<0.05)$ and if the $\mathrm{t}$-value greater than $2.58 \quad(p<0.01)$ then the hypothesized associations are supported and strongly significant (see Table4).

\begin{tabular}{|c|c|c|c|c|c|}
\hline Hypothesis & Relationship & Std.Beta & Std.Error & $\mathrm{t}$-value & Decision \\
\hline H1 & A $>$ E & 0.186 & 0.080 & $2.319 * *$ & Supported \\
\hline H2 & G->F & 0.357 & 0.064 & $5.563 * *$ & Supported \\
\hline H3 & G $>$ K & 0.281 & 0.055 & $5.078 * *$ & Supported \\
\hline H4 & K->F & 0.190 & 0.052 & $3.631 * *$ & Supported \\
\hline H5 & S->A & 0.478 & 0.043 & $\begin{array}{c}10.912 * \\
*\end{array}$ & Supported \\
\hline H6 & S->E & 0.293 & 0.065 & $4.461 * *$ & Supported \\
\hline H7 & SNGA $>$ A & 0.296 & 0.040 & $7.335 * *$ & Supported \\
\hline
\end{tabular}




\begin{tabular}{|c|c|c|c|c|c|}
\hline $\mathrm{H} 8$ & SNGA->E & 0.147 & 0.059 & $2.498 * *$ & Supported \\
\hline H9 & SNGA $->F$ & 0.187 & 0.061 & $3.053 * *$ & Supported \\
\hline H10 & $\mathrm{SNGA}->\mathrm{G}$ & 0.432 & 0.065 & $6.575 * *$ & Supported \\
\hline H11 & SNGA $->\mathrm{K}$ & 0.075 & 0.063 & 1.193 & $\begin{array}{c}\text { Not } \\
\text { Supported }\end{array}$ \\
\hline H12 & SNGA $\rightarrow$ S & 0.436 & 0.059 & $7.350 * *$ & Supported \\
\hline \multicolumn{6}{|l|}{$\begin{array}{l}\text { Note } \\
\mathrm{t}-\mathrm{va} \\
\mathrm{t}-\mathrm{val} \\
\text { tha }\end{array}$} \\
\hline
\end{tabular}

Table 4. Hypothesis Testing

Interestingly, the model showed the significant effects of the interaction between H1, H2, H3, H4, H5, H6, H7, H8, H9, H10 \& H12. As well as the clear role of flow as an antecedent to other constructs, the model shows a fit and has greater explanatory results H1 (2.319), H2 (5.563), H3 (5.078), H4 (3.631), H5 (10.912), H6 (4.461), H7 (7.335), H8 (2.498), H9 (3.053), H10 (6.575) \& H12 (7.350).

The findings of this study advance previous studies by clarifying the relationship between Functional (F), Keystroke (K), Goal (G), Emotion (E), Social (S), Affection (A) and SNGs Addictions (SNGA) in an SNG context. Only one hypothesis decision $t$-value not supported that is involved the relationship between SNGA --> Keystroke, H11 (1.193). It might be the factors between these two variables not strong enough to be connected (see Table 4). 


\section{Conclusions}

The findings provide several theoretical implications. First, excepting users initial usage intention in social networking, the findings broaden and emphasize the ability of the concepts of interaction and value to predict whether individuals will continuously use the games in a social network environment. Second, the theoretical integration of the user satisfaction with continuance intentions in the perspectives of IT/IS, ${ }^{25)}$ and the links between flow experience and continuance intentions, this study makes several unique contributions to this integration.

This study aids understanding of user behaviors associated with SNGs and development of effective models. As users accept SNGs as a new way to entertain and bond with others, escape from reality, and communicate with others, and as firms provide enabling platforms for users, SNGs might evolve into a brilliantly effective application.

To ensure their continued popularity, however, SNGs have several challenges to overcome, and user acceptance is probably the most important one. SNG developers need a better understanding of individual perceptions concerning the level of trust and the influence of security on intention to use. The findings of this study provide a good basis for industry to develop a service evaluation framework that determines the adoption potential of new services under the Web3.0 environment. The model is well suited for developing such a framework for services adopted for

25) Kang,Y., Lee,H., "Understanding the role of an IT artifact in online service continuance: An extended perspective of user satisfaction", Computers in Human Behavior, Vol. 26 (2010), pp. 353-364. 
functional reasons and services directed specifically at innovative user attitudes.

This study has several limitations that lead to suggestions for future research. The first limitation is external validity because a convenience sampling of SNG users from the various backgrounds was used. Thus, while the findings from this study may be extended to other similar technology centered initiatives in different countries, the generalize-ability to other nations may be limited to a certain degree. Responding users might not represent the whole population, because most users of SNGs are still young people. The subjects of the study were recruited as representatives of young users. Thus, this study does not provide a comprehensive picture of entire SNG communities but only provides a snapshot of a subset of users.

Despite several limitations, this study took an exploratory step towards examining user experiences on still-emerging social technologies and found a number of metrics that are reliable and valid. Many issues remain unresolved and several questions remain unanswered as SNGs on Web2.0 drastically evolve to Web3.0. SNGs on Web2.0 emphasize the social side of the online world, but we expect SNGs on Web3.0 to involve developed applications that emphasize focused groups with specialized features.

This research develops Social Network Games Addiction (SNGA) model. We anticipated that Functional (F), Keystroke (K), Goal (G), Emotion (E), Social (S) and Affection (A) that derived towards SNGs Addictions (SNGA) and explain why people continue to play SNGs. SNGs would jointly determine individuals continuance intentions, and that the continuance intention may be mediated by individuals flow experience 
with SNGs. This research contributes to the limited body of SNG research, positions SNG addictions and impacts in the flow context, and explores drivers of several of characteristic in the contexts of SNGs.

\section{References}

Andreou,E., Svoli,H., "The Association Between Internet User Characteristics and Dimensions of Internet Addiction Among Greek Adolescents", International Journal of Mental Health and Addiction, Vol.11(2013), pp. 139-148.

Brian, D. N., Peter, W., "Addiction to the Internet and Online Gaming", CyberPsychology \& Behavior, Vol.8(2005), pp. 110-113.

Chalmers,P.A., "The role of cognitive theory in human-computer interface", Computers in Human Behavior, Vol.19 (2003), pp. 593-607.

Choi, H., Choi,E., and Song.S., "The structure of affection descriptors for social network game: case study of CityVille on facebook", Multimedia Tools and Applications, Vol.68 (2014), pp. 375-389.

Dijkstra,T.K., "Latent variables and indices: Herman Wold' s basic design and partial least squares", In: Vinzi VE, Chin WW, Henseler J, Wang H (eds) Handbook of partial least squares, Springer Handbooks of computational statistics, 2010, pp. 23-46.

Gray,W.D., John, B.E., and Atwood,M.E., "Project Ernestine: Validating a GOMS analysis for predicting and explaining real-world task performance", Human Computer Interaction, Vol.8.(1993), pp. 237-309.

Griffiths,M.D., Davies,M.N.O., and Chappell,D., "Online computer gaming: a comparison of adolescent and adult gamers", Journal of Adolescence, Vol.27(2004), pp. 87-96. 
Hair,J.F.Jr., Hult,G.T.M., Ringle, C., Sarstedt, M., A Primer on Partial Least Squares Structural Equation Modeling (PLS-SEM), SAGE Publications, 2014.

Hardie, E., Tee, M.Y., "Excessive Internet Use: The Role of Personality, Loneliness and Social Support Networks in Internet Addictions", Australian Journal of Emerging Technologies and Society, Vol.5(2007), pp. 34-47.

Hargittai,E., "Whose space? Differences among users and non-users of social network sites", Journal of Computer-Mediated Communication, Vol.13(2008), pp. 276-297.

Isbister,K., Schaffer,N., Game Usability: Advancing the Player Experience, Morgan Kaufmann, MA 2008, pp 317-343.

Janet, M., "Internet Abuse: Emerging Trends and Lingering Questions", in Azy Barak,(eds.), Psychological aspects of cyberspace: theory, research, applications, Cambrigde, 2008.

John,B.E., Kieras,D.E., "The GOMS family of user interface analysis techniques: comparison and contrast", Journal ACM Transactions on Computer-Human Interaction (TOCHI), Vol.3 (1996), pp. 320-351.

Kang,Y., Lee,H., "Understanding the role of an IT artifact in online service continuance: An extended perspective of user satisfaction", Computers in Human Behavior, Vol. 26 (2010), pp. 353-364.

Ko,C., Hsiaod,S., Liud,G., Yena,J., Yang,M., Yen,C., "The characteristics of decision making, potential to take risks, and personality of college students with Internet addiction", Psychiatry Research, Vol.175 (2010), pp. 121-125.

Kuss,D.J., Griffiths,M.D., and Binder,J.F., "Internet addiction in students: Prevalence and risk factors", Computers in Human Behavior, Vol.29(2013), pp. 959-966.

Lam,L.T., Peng,Z., Mai,J., Jing, J., "Factors Associated with Internet Addiction among Adolescents", CyberPsychology \& Behavior, Vol.12(2009), pp. 551-555.

Lee,S., Yang, S., Human Sensibility Ergonomics , ChungMoonKak, 1996. 
Mun,Y., and Hwang,Y., "Predicting the use of web-based information systems: self-efficacy, enjoyment, learning goal orientation, and the technology acceptance model." International journal of human-computer studies, Vol.59 (2003), pp. 431-449.

Nicole.L., "Why we play games: Four keys to more emotion without story",

ht tp: // www.xeodesign.com/xeodesign_whyweplaygames.pdf 2015.7.28.

Ruan, X.,Cho, D., "Relation between Game Motivation and Preference to Cutscenes", The Korean Society of Cartoon \& Animation Studies, Vol. 36(2014), pp.573-592.

Shin, D., Shin, Y., "Why do people play social network games?", Computers in Human Behavior, Vol.27(2011), pp.852-861.

Siang,A.C.,Zaphiris,P., and Mahmood,S., "A model of cognitive loads in massively multiplayer online role playing games", Interacting with computers, Vol.19(2007), pp. 167-179.

Song, I. ,Larose, R. ,East in, M.S., Lin, C.A. , "Internet Grat if icat ions and Internet Addiction: On the Uses and Abuses of New Media", CyberPsychology \& Behavior, Vol. 7(2004), pp.384-394.

Statistics Facebook, 2015,

ht tp://www.stat ista.com/stat istics/264810/number-of-monthlyactive- facebook-users-worldwide/ 2015.7.28. 


\title{
ABSTRACT
}

\section{The Proposal for the Model of Users' Addictions in Social Gaming}

\author{
Tengku Fauzan Tengku · Anuar, Song, Seung-Keun
}

The objective of this study proposes the new user's addiction model in 'Social Network Games' (SNGs). Research model is derived from the separation of two characteristics. First one is logical characteristics that includes 'Functional' (F), 'Keystroke' (K), and 'Goal' (G). Second one is feeling characteristics that consists a few factors such as 'Emotion' (E), 'Social' (S), and 'Affection' (A). For the pre-test, a total of 30 participants responded to survey in order to inspect the fitness of research questionnaire, roughly validity of the proposed model, and the direction of this reseach. After that for the main test, a total 300 users participated in this research. The final number of effective participants were 261 because 39 were insincere respondents and without playing SNGs who were excluded. Then we examined the measurement model by performing 'Partial Least Squares - Structural Equation Modeling' (PLS-SEM) analysis to test the research hypothesis empirically. The results of the measurement and structural model test lend support to the proposed research model by providing a good fit to the construct data. Interestingly, the model showed the significant effects of the interaction between eleven hypothes is ( $\mathrm{H1}, \mathrm{H} 2, \mathrm{H} 3, \mathrm{H} 4, \mathrm{H} 5, \mathrm{H} 6, \mathrm{H} 7, \mathrm{H} 8, \mathrm{H} 9, \mathrm{H} 10, \quad \mathrm{H} 12)$. Only one hypothesis decision t-value not supported that is involved the relationship between SNGs Addiction and Keystroke, H11(1.193). This research expect to contributes to an exploratory SNGs research to clarify the base of addition and will aids understanding of users' behavior associated with SNGs development.

Key Word : Addictions, Social Gaming, Structural Equation Model ing 
주저자 Tengku Fauzan Tengku Anuar 동서대학교 디자인전문대학원 디자인학과 박사 재학 (617-716) 부산광역시 사상구 주례로 47 Tel : 051-320-2649 jayjan.jayjan@gmail.com 교신저자 송승근 동서대학교 디지털콘텐츠학부 교수 (617-716) 부산광역시 사상구 주례로 47 Tel : 051-320-1703 songsk@gdsu.dongseo.ac.kr

논문투고일 : 2015.07.29. 심사종료일 : 2015.08.20. 게재확정일 : 2015.08.28. 